\title{
PAROTID GLAND METASTASES OF OTHER PRIMARY TUMORS - A 10 YEAR RETROSPECTIVE STUDY
}

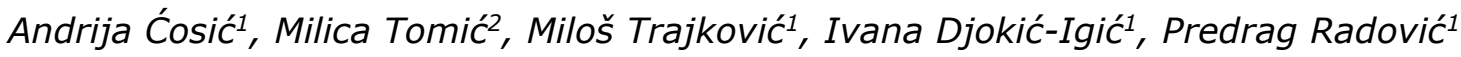

\begin{abstract}
Metastatic cancers of the parotid are very rear and hard to diagnose neoplasms. They can be classified into two major groups: tumors with supraclavicular and inflaclavicular primary localization. Squamous cell carcinoma of the skin is the most common histological type found; it is followed by melanoma, Merkel cell carcinoma and adenocarcinoma of the lungs. We analyzed 420 patients that were diagnosed with parotid gland tumors at the department of Maxillofacial surgery, Clinic of Dentistry in Niš, from 2007 to 2017. In 121 patients pathohistological findings showed malignant tumors out of which 21 were metastatic. Radical parotidectomy with adjuvant radiotherapy of the head and neck region was the most common type of treatment. Neck dissection was performed in all of the patients but the extent of it depended on the clinical findings. Lymph nodes were negative for the metastatic disease in only 4 patients. Survival rate is very different among patients ranging from 8 to 138 months.
\end{abstract}

Acta Medica Medianae 2019;58(3):80-84.

Key words: parotid tumors, metastases, therapy

${ }^{1}$ University of Niš, Faculty of Medicine, Department of

Maxillofacial Surgery, Clinic of Dentistry, Niš, Serbia

2University of Niš, Faculty of Medicine, Serbia

Contact: Andrija Ćosić

Blvd. Dr Zoran Djindjić 81, 18000 Niš, Serbia

E-mail: cosa72@yahoo.com

\section{Introduction}

Salivary gland tumors occur in about $3 \%$ of all head and neck tumors. The most common of them are parotid gland tumors; they appear in almost $80 \%$ (1). Parotid cancers are uncommon and they develop in less than $20 \%$ of all parotid tumors, but they are very, histologically and biologically, diverse group of neoplasms $(1,2)$. There are two major groups of parotid gland cancers; primary salivary gland tumors and metastatic cancers. Metastatic cancers can develop by direct extension through neighboring tissues, lymphatic channels, or less commonly, through haematogenous spread (3). The site of the primary tumor is usually the skin of the head and neck, thus being squamous cell carcinoma or melanoma (3). Infraclavicular or noncutaneous cancers of the head and neck are far less often found $(4,5)$.
Clinical findings in patients with metastatic tumors of parotid gland may vary from severe where facial nerve is also infiltrated, to mild, benign-like tumors.

The aim of this study was to show clinical and pathohistological (ph) findings in patients with metastatic cancers of the parotid as well as therapeutic procedures used and the survival rate in these patients treated in our clinic.

The study analyzed 420 parotidectomies performed at the Department of Maxillofacial surgery, Clinic of Dentistry in Niš during the period from 2007 to 2017. All patient data were obtained by hand searching of patient records. Data were maintained in an anonymised database and analyzed using a statistical software package. Medical information that was analyzed consisted of sex and age of patients, primary localization of tumors, treatment, pathohistological findings and treatment of metastases.

\section{Results}

Total number of parotidectomies was 420 . Malignant tumors were confirmed in 121 (28.8\%) cases. Including criteria: metastatic tumor of the parotid gland. Excluding criteria: primary cancer of parotid, lymphoma, metastatic tumors with an unknown origin. These criteria were met by $21(5 \%)$ cases, 10 male and 11 female patients, 55 to 87 years of age.

Most commonly, primary tumors were located in the head and neck (95.24\%). Squamous cell carcinoma (SCC) was seen in 13 cases, five patients had melanoma and Merkel cell carcinoma was re- 
corded in two cases. There was only one tumor that was primary located below clavicle, it was adenocarcinoma of the lungs. (Table 1)

In patients with SCC, there were 4 cases where the pathohistological examination of the neck lymph nodes showed no traces of the disease in the neck which is why these patients received radiotherapy only in the parotid region. Surgical treatment and adjuvant radiotherapy are shown in Tables 2 and 3 .

Survival rate is very diverse, ranging from 8 to 135 months (Table 4).

Table 1. Sites of tumors that metastasized to the parotid gland

\begin{tabular}{||l|c|c||}
\hline Site & No. of cases & $(\%)$ \\
\hline \hline Cutaneous, head and neck & $\mathbf{2 0}$ & $\mathbf{9 5 . 2 4 \%}$ \\
- Squamous cell carcinoma (SCC) & 13 & $(61.9 \%)$ \\
- Melanoma & 5 & $(23.8 \%)$ \\
- Merkel cell carcinoma (MCC) & 2 & $(9.54 \%)$ \\
\hline \hline Infraclavicular & $\mathbf{1}$ & $\mathbf{4 . 7 6 \%}$ \\
- Lung, adenocarcinoma & 1 & $(4.76 \%)$ \\
\hline
\end{tabular}

Table 2. Extent of surgery for the Parotid and the Neck

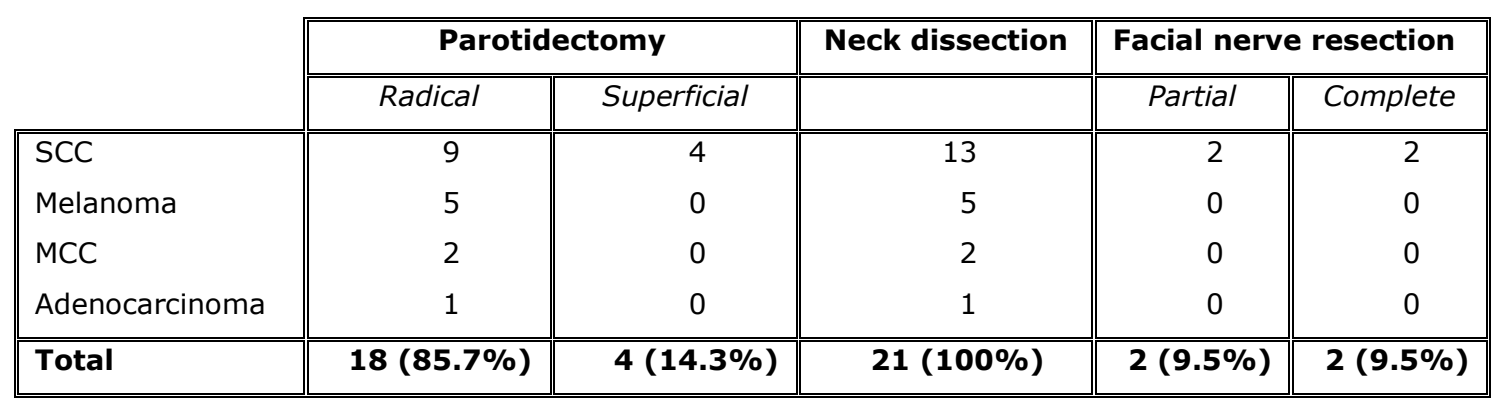

Table 3. Adjuvant radiotherapy

\begin{tabular}{|c|c|c|}
\hline & Parotid region only & $\begin{array}{c}\text { Parotid region with } \\
\text { the neck }\end{array}$ \\
\hline SCC & 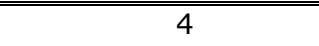 & 9 \\
\hline Melanoma & 0 & 5 \\
\hline MCC & 0 & 2 \\
\hline Adenocarcinoma & 0 & 1 \\
\hline Total & $4(19.05 \%)$ & $17(80.95 \%)$ \\
\hline
\end{tabular}

Table 4. Survival rate of patients with metastatic tumors of the parotid (in months)

\begin{tabular}{|l||c||c||c||}
\hline \hline Type of the cancer & Min & Max & Alive \\
\hline \hline SCC & 8 & 135 & 4 (30 month follow up) \\
Melanoma & 8 & 76 & 2 (31 month follow up) \\
MCC & 10 & 20 & 1 (20 month follow up) \\
Adenocarcinoma & 13 & 13 & 0 \\
\hline
\end{tabular}




\section{Discussion}

The majority of tumors metastasizing into the parotid gland originate from the skin of the head and neck (6). In our study, that is the case in 95.24 percent. It is no surprise that this happens considering the lymph drainage paths of the skin of the face, scalp and neck. The literature shows small number of cases where the primary tumor was located below clavicle (5-7), which is the same in our study, where only one infraclavicular localization was found. Squamous cell carcinoma is the most common histological type $(2,3,8)$ and that is the case in our study in $61.9 \%$. In therapeutic terms, there is no difference whether metastases are located in the parotid parenchyma or in the parotid lymph nodes (9). Supraclavicular tumors metastasize in the parotid region usually through lymphogenous routes or per continuitatem, depending on the localization unlike the infraclavicular tumors which usually spread through haematogenous routes. There are even discussions about metastases in the parotid lymph nodes being an expression of lymphogenous metastases whereas parenchymal metastasis is an indication for haematogenous metastasis (10).

Before considering treatment for patients with parotid cancers, it is very important to make a clear distinction between primary and metastatic disease. Parotid metastases in some cases are the first clinical manifestation of a previously unknown tumor (10). Primary tumors can be treated less offensive, with or without neck dissection or adjuvant radiotherapy whereas metastatic cancers demand radical approach (11). In our study, radical parotidectomy was made in $80.95 \%$ and superficial parotidectomy (SP) in $19.05 \%$. We agree with the opinion of Malata (12) that SP is an adequate solution when cancer has spread only in the superficial lobe of the gland. McKean et al. (13) investigated parotid glands on cadavers and they have come to conclusion that 222 lymph nodes of the parotid are located in the superficial lobe whereas only 0-4 are located in the deep lobe. The reason for $80.95 \%$ of radical parotidectomies in our case is that the patients have reached out to us when the cancer has already spread tremendously. All of the patients had surgical treatments that included neck dissection, in five cases it was selective neck dissection (SND) and the rest was modified radical neck dissection (MRND). SND was performed in patients that had no clinical signs of enlarged lymph nodes (we had no possibility of making CT and NMR scans routinely). Our decision to do the neck dissection in patients whose ultra- sound of the lymph nodes showed no evidence of the disease is in compliance with Jackson and Ballantine (14) as well as Marks et al. (15) They have made confirmation of the metastases in the neck after ph examination in $24 \%$ of the cases that had no clinical signs of the disease. We did SND in five patients with no clinical signs of the disease and for one patient $(20 \%)$ the ph confirmation came back positive. In 2 cases or $9.5 \%$ facial nerve had to be sacrificed and in the same number of cases we had to make a partial nerve resection. Studies have shown that adjuvant radiotherapy to the parotid region is given to $78 \%$ of patients (10). All of our patients received postoperative radiotherapy, in 19.05\% it was just in the parotid region, but the majority $(80.95 \%)$ received radiotherapy in the parotid region as well as the neck because of the positive lymph nodes.

Survival rate depends on the number of factors among which are primary location and the staging of the tumor, general condition of the patient, histological type etc., but the best prognosis is for the patients with the SCC that is caught early.

High mortality rate shows just how aggressive these tumors are and is in compliance with the literature $(2,6,10)$.

\section{Conclusion}

Metastatic tumors of the parotid were confirmed in $5 \%$ of all parotid tumors. In $61.9 \%$ it was squamous cell carcinoma originating from the skin of the head and neck. There was only one case of noncutaneous and infraclavicular localization, adenocarcinoma of the lungs, that metastasized to the parotid. Radical parotidectomy was performed in $85.7 \%$, but neck dissection and adjuvant radiotherapy were part of the treatment in every patient. In $81 \%$ of patients, complete preservation of the facial nerve was achieved.

Establishing the right diagnosis is the essential part of managing this type of disease. Radical approach is necessary when dealing with metastatic cancers, but we should always keep in mind that we do not treat tumors, we treat patients. Palliative care is sometimes the only possible treatment that we can provide and it should also be considered when proposing therapy to our patients.

\section{Conflict of interest}

Authors declare no conflict of interest. 


\section{References}

1. Piscevic A, Gavric M, Sjerobabin I. Maksilofacijalna hirurgija. $1^{\text {st }}$ ed. Belgrade: "Draganic" publisher; 2001.

2. Spiro RH. Diagnosis and pitfalls in the treatment of parotid tumors. Sem Surg Oncol 1991;7:20-4.

[CrossRef]

3. Batsakis JG, Bautina E. Metastases to major salivary glands. Ann Otol Rhinol Laryngol 1990;99:501-3. [PubMed] [CrossRef]

4. Nuyens M, Schüpbach J, Stauffe E, Zbären P. Metastatic disease to the parotid gland. Otolaryngol Head Neck Surg 2006;135:844-8. [PubMed] [CrossRef]

5. Künze J, Agaimy A, Krause SW, Vieth M, Alexiou C. Isolated late metastasis from testicular seminoma presenting as a parotid gland mass: case report and review of the literature. Curr Oncol 2013;20:e354-8. [PubMed] [CrossRef]

6. Bron LP, Traynor SJ, McNeil EB, O'Brien CJ. Primary and metastatic cancer of the parotid: comparison of clinical behavior in 232 cases. Laryngoscope 2003; 113:1070-5. [PubMed] [CrossRef]

7. Li L, Friedrich RE, Schmelzle R, Donath K. Metachronous bilateral metastases of renal cell carcinoma to the parotid region. J Oral Maxillofac Surg 2001; 59:434-8. [PubMed] [CrossRef]

8. Pomar Blanco P, Martın Villares $C$, San Roman Carbajo J, Tapia Risueno M, Fernandez Pello M. Metastasis to the parotid gland. Acta Otorrinolaringol Esp 2006; 57:47-50. [CrossRef]
9. Olsen $\mathrm{KD}$, Moore EJ, Lewis JE. Frozen section pathology for decision making in parotid surgery. JAMA Otolaryngol Head Neck Surg 2013;139:1275-8. [PubMed] [CrossRef]

10. Franzen AM, Gunzel T, Lieder A. Parotid gland metastases of distant primary tumours: a diagnostic challenge. Auris Nasus Larynx 2016;43(2):187-91. [PubMed] [CrossRef]

11. Thom JJ, Moore EJ, Price DL, Kasperbauer JL, Starkman SJ, Olsen KD. The role of total parotidectomy for metastatic cutaneous squamous cell carcinoma and malignant melanoma. JAMA Otolaryngol Head Neck Surg 2014;140:548-54. [PubMed] [CrossRef]

12. Malata CM, Camilleri IG, McLean NR, Piggot TA, Soames JM. Metastatic tumors of the parotid gland. $\mathrm{Br}$ J Oral Maxillofac Surg 1998;36(3):190-5. [PubMed] [CrossRef]

13. McKean ME, Lee K, McGregor IA. The distribution of lymph nodes in and around the parotid gland: an anatomical study. Br J Plast Surg 1985;38:1-5. [PubMed] [CrossRef]

14. Jackson GL, Ballantine AJ. Role of parotidectomy for skin cancer of head and neck. Am J Surg 1981;142: 464-9. [PubMed] [CrossRef]

15. Marks MW, Ryan RF, Litwin MS, Sonntag BV. Squamous cell carcinoma of the parotid gland. Plast Reconstr Surg 1987;79:550-4. [PubMed][CrossRef] 


\title{
METASTATSKI TUMORI PAROTIDNE ŽLEZDE - DESETOGODIŠNJA RETROSPEKTIVNA STUDIJA
}

\author{
${ }^{1}$ Univerzitet u Nišu, Medicinski fakultet, Odeljenje za maksilofacijalnu hirurgiju, \\ Klinika za Stomatologiju,Niš, Srbija \\ ${ }^{2}$ Univerzitet u Nišu, Medicinski fakultet, Niš, Srbija \\ Kontakt: Andrija Ćosić \\ Bulevar dr Zoran Đjinđić 81, 18000 Niš, Srbija \\ E-mail: cosa72@yahoo.com
}

Andrija Ćosić ${ }^{1}$, Milica Tomić ${ }^{2}$, Miloš Trajković ${ }^{1}$, Ivana Đokić-Igić1 ${ }^{1}$ Predrag Radović ${ }^{1}$

Maligni tumori parotidne žlezde se mogu razviti kao primarni tumori ili nastati metastaziranjem malignih neoplazmi u limfne noduse parotidne regije. Prema poreklu primarne lezije, metastatski tumori parotidne žlezde se dele na one koji nastaju od tumora lokalizovanih supraklavikularno i infraklavikularno. Supraklavikularni tumori dominiraju kao uzročnici metastaza u parotidnoj žlezdi, a patohistološki je najčešći planocelularni karcinom kože glave i vrata, zatim melanom, karcinom Merkelovih ćelija, dok infraklavikularno najčešće metastazira adenokarcinom pluća. $U$ radu je analizirano 420 bolesnika koji su lečeni od tumora parotidne žlezde u Službi za maksilofacijalnu hirurgiju Klinike za stomatologiju u Nišu u periodu od 2007. godine do 2017. godine. Kod 121 bolesnika je potvrđen maligni karakter bolesti, a za potrebe studije je analizirano njih 21 , kod kojih je postavljena dijagnoza metastatske maligne bolesti. Najveći broj bolesnika je lečen radikalnom parotidektomijom, a nakon toga i zračnom terapijom. Kod svih bolesnika je rađena disekcija vrata, ali se obim disekcije razlikovao u zavisnosti od kliničke slike. Kod samo četiri bolesnika nije dokazano postojanje metastatske bolesti u limfnim nodusima. Vreme preživljavanja se kreće u opsegu od 8 meseci do 138 meseci.

Acta Medica Medianae 2019;58(3):80-84.

Ključne reči: tumori parotidne žlezde, metastaze, terapija 